\title{
Effect of triptolide on the regulation of ATP-binding cassette transporter A1 expression in lipopolysaccharide-induced acute lung injury of rats
}

\author{
JUN CHEN, JIANLIN GAO, JIANPING YANG, YUKUN ZHANG and LINA WANG
}

Department of Anesthesiology, First Affiliated Hospital, Soochow University, Suzhou, Jiangsu 215006, P.R. China

Received September 9, 2013; Accepted July 21, 2014

DOI: $10.3892 / \mathrm{mmr} .2014 .2636$

\begin{abstract}
The aim of this study was to investigate the effect of triptolide on ATP-binding cassette transporter A1 (ABCA1) expression in lipopolysaccharide (LPS)-induced acute lung injury (ALI) in rats. Thirty male Sprague Dawley rats weighing 200-250 g were randomly divided into six groups: Normal (N, $\mathrm{n}=5)$, Control $(\mathrm{C}, \mathrm{n}=5)$, LPS $(\mathrm{L}, \mathrm{n}=5)$, Triptolide $25 \mu \mathrm{g}\left(\mathrm{TP}_{1}\right.$, $\mathrm{n}=5)$, Triptolide $50 \mu \mathrm{g}\left(\mathrm{TP}_{2}, \mathrm{n}=5\right)$ and Triptolide $100 \mu \mathrm{g}\left(\mathrm{TP}_{3}\right.$, $\mathrm{n}=5$ ). The $\mathrm{N}$ group was not administered anything; the $\mathrm{C}$ group was administered $5 \mathrm{ml} / \mathrm{kg}$ normal saline intravenously and $7.5 \mathrm{ml} / \mathrm{kg} \mathrm{1 \%}$ dimethylsulfoxide (DMSO) intraperitoneally; the L group was administered $5 \mathrm{mg} / \mathrm{kg} 0.1 \%$ LPS and $1 \%$ DMSO; and the $\mathrm{TP}_{1}, \mathrm{TP}_{2}$ and $\mathrm{TP}_{3}$ groups were separately injected with $0.1 \% \mathrm{LPS}$ and 25,50 or $100 \mu \mathrm{g} / \mathrm{kg}$ triptolide, respectively. All groups had the same liquid-injection volume. Arterial blood gases, tumor necrosis factor- $\alpha$ (TNF- $\alpha)$ and ABCA1 expression and general pathology were examined following the treatments. It was found that increasing the triptolide dose in the $\mathrm{TP}_{1-3}$ groups resulted in an increase in the expression of ABCA1 mRNA and protein. As compared with the L group, the ABCA1 expression showed a significant increase in $\mathrm{TP}_{2}$ and $\mathrm{TP}_{3}$ groups $(\mathrm{P}<0.05)$. In addition, the expression level of TNF- $\alpha$ was significantly increased in the $\mathrm{L}$ and $\mathrm{TP}_{1}$ groups, as compared with that in the $\mathrm{N}$ or $\mathrm{C}$ groups $(\mathrm{P}<0.05)$. Conversely, a marked decrease in TNF- $\alpha$ expression was detected in the $\mathrm{TP}_{2}$ and $\mathrm{TP}_{3}$ groups, as compared with the $\mathrm{L}$ or $\mathrm{TP}_{1}$ groups $(\mathrm{P}<0.05)$. In conclusion, this study found that triptolide could promote the expression of ABCA1 mRNA and protein and inhibit other inflammatory factors during LPS-induced ALI in rats. Regulating the expression of ABCA1 may be one of the protective mechanisms of triptolide. Furthermore, triptolide-induced increases in ABCA1 expression occurred in a dose-dependent manner between 25 and $100 \mu \mathrm{g} / \mathrm{kg}$.
\end{abstract}

Correspondence to: Dr Jianping Yang, Department of Anesthesiology, First Affiliated Hospital, Soochow University, 188 Shizi Street, Suzhou, Jiangsu 215006, P.R. China E-mail: jianpingyangcn@163.com

Key words: acute lung injury, lipopolysaccharide, diterpenes, immunosuppressive agents, ATP-binding cassette transporter A1

\section{Introduction}

Acute lung injury (ALI) and acute respiratory distress syndrome (ARDS) are common and severe conditions, with high mortality rates. ALI/ARDS most seriously affects those with existing medical conditions, affecting both the quality of life and chance of survival in patients (1). The pathogenesis of the condition has not been fully elucidated; however, it is known that the pathophysiological basis involves a loss of control of the regulatory network consisting of cells, cytokines and inflammatory mediators. This leads to the damage of target cells, including pulmonary capillary endothelial and alveolar epithelial cells (2-5). Previous studies (6-8) have shown that ATP-binding cassette transporter A1 (ABCA1) has an essential effect on the regulation of the inflammatory response. ABCA1-mediated cholesterol efflux can reduce the inflammatory signaling induced by lipopolysaccharide (LPS) in cell membrane. The metabolic balance between cholesterol and phospholipids has an important effect on the inflammatory response. Phospholipids are key components of surface-active substances, and a decrease in phospholipid content can aggravate lung collapse (9). Bates et al (10) indicated that ABCA1-knockout mice manifest low levels of high-density lipoprotein and exhibit lung morphological abnormalities. Lipid analysis of the alveolar lavage fluid suggested that the quantity and metabolism of phospholipids in the lung tissues were abnormal. Considering the high distribution of ABCA1 in the lungs under physiological conditions, it is speculated that ABCA1 may be involved in the pathogenesis of ALI/ARDS. Triptolide is a diterpene lactone epoxide compound with high biochemical activity. The compound is isolated from Celastraceae tripterygium (Tripterygium wilfordii Hook. f.) and has been shown to have extensive pharmacological effects and a potent immunomodulatory capacity $(11,12)$.

It has yet to be elucidated whether TP can recover the balance of the systemic inflammatory response and the compensatory anti-inflammatory response systems, relieve the pathological changes of ALI/ARDS and improve prognosis by regulating the transcription and protein expression of ABCA1 and inhibiting or reducing the release of inflammatory cells, transmitters and cytokines. The aim of the present study was to generate a rat model of ALI mediated by LPS, in order to investigate the in vivo changes in the transcription and protein expression of ABCA1 and the protective effects of triptolide on LPS-mediated rat ALI. 


\section{Materials and methods}

Materials. LPS (E. coli O111:B4; lot no. L2630) and 1\% dimethylsulfoxide (DMSO, lot no. D5879) were purchased from Sigma (St. Louis, MO, USA). Triptolide (dissolved with $1 \%$ DMSO; lot no. 20090321) was obtained from the Nanjing Skin Disease Prevention Institute (Nanjing, China), and a blood gas analyzer was purchased from Nova Biomedical (Waltham, MA, USA). A tumor necrosis factor- $\alpha$ (TNF- $\alpha$ ) ELISA kit (article no. HY12849E) was obtained from R\&D Systems (Minneapolis, MN, USA). ABCA1 monoclonal antibody (article no. p3490RB) was purchased from R\&D Systems (Minneapolis, MN, USA), GAPDH antibody (article no. sz-293072) was obtained from Santa Cruz Biotechnology, Inc., (Santa Cruz, CA, USA) and rabbit anti-mouse immunoglobulin $\mathrm{G}(\operatorname{IgG})$ (article no. KTB4027) was purchased from Shanghai Boyao Biological Technology Co., Ltd., (Shanghai, China). A LightCycler 480 fluorescent quantitative polymerase chain reaction (qPCR) instrument was obtained from Roche Diagnostics (Indianapolis, IN, USA), TRIzol ${ }^{\mathrm{TM}}$ RNA extraction solution (article no. 15596018) was purchased from Invitrogen Life Technologies (Carlsbad, CA, USA), a bicinchoninic acid (BCA) protein quantification kit (article no. SK3021-500) was ordered from Shanghai Sangon (Shanghai, China) and SDS (article no. H10236) was obtained from Sigma.

Laboratory animals and groups. Thirty male Sprague Dawley rats, weighing 200-250 g, were provided by Shanghai Laboratory Animal Center, CAS (Shanghai, China). The rats were randomly distributed into six groups as follows: Normal ( $N$ group, $n=5$ ), Control (C group, $n=5)$, LPS (L group, $n=5$ ) and three triptolide dosage groups $\left(\mathrm{TP}_{1-3}\right.$ groups, $\mathrm{n}=5 /$ group$)$. Rats in the $\mathrm{L}$ and $\mathrm{TP}_{1-3}$ groups were injected with $5 \mathrm{mg} / \mathrm{kg} \mathrm{LPS}$ (dissolved with normal saline) via the vena caudalis, as previously described (13), and the $\mathrm{TP}_{1-3}$ groups were additionally administered an intraperitoneal injection of triptolide at 25 , 50 or $100 \mu \mathrm{g} / \mathrm{kg}$, respectively. Rats in the $\mathrm{N}$ group were not treated. Rats in the $\mathrm{C}$ group were injected with normal saline via the vena caudalis and were intraperitoneally injected with $1 \%$ DMSO. The present study was approved by the Animal Care and Use Committee of Soochow University (Suzhou, China).

Arterial blood gas analysis. Arterial blood samples $(0.3 \mathrm{ml})$ were collected $1 \mathrm{~h}$ before treatment administration and 1,3, 6 and $12 \mathrm{~h}$ after treatment for blood gas analysis. Data of the arterial oxygen tension $\left(\mathrm{PaO}_{2}\right)$ were collected.

Collection and storage of samples. Rats were anesthetized with $4 \%$ chloral hydrate at a dose of $400 \mathrm{mg} / \mathrm{kg}, 12 \mathrm{~h}$ after treatment administration. A thoracotomy was then performed and the trachea and left and right bronchi were exposed and isolated. Animals were then sacrificed by exsanguination, taking blood from the left heart $12 \mathrm{~h}$ after administration. The left bronchus was clipped using a vascular clamp. An intravenous $24 \mathrm{G} \mathrm{Y}$ type trocar (BD Biosciences, San Jose, CA, USA) was placed in casing along the tracheal ring gap, below the middle section of the trachea. Normal saline at $4^{\circ} \mathrm{C}$ was used for bronchoalveolar lavage, repeated three times, at a total dose of $25 \mathrm{ml} / \mathrm{kg}$. The bronchoalveolar lavage fluid (BALF) was obtained and, following centrifugation at $241 \mathrm{x} \mathrm{g}$ for $10 \mathrm{~min}$ at $4^{\circ} \mathrm{C}$, the supernatant was stored at $-20^{\circ} \mathrm{C}$. The blood samples were anticoagulated with heparin and then centrifuged at $671 \mathrm{x} \mathrm{g}$ for $20 \mathrm{~min}$ at $4^{\circ} \mathrm{C}$. The supernatant was then stored at $-20^{\circ} \mathrm{C}$.. The concentration of TNF- $\alpha$ in the serum and BALF was measured by double-antibody sandwich ELISA (R\&D Systems).

The rats were sacrificed and fresh lung tissues were collected from the inferior lobe of the right lung. The tissues were washed with normal saline at $4^{\circ} \mathrm{C}$ and then placed on ice. Ophthalmic scissors soaked in diethylpyrocarbonate-treated water were used to collect $\sim 100 \mathrm{mg}$ tissue, which was then transferred to a centrifuge tube containing a five-fold volume of RNAlater ${ }^{\circledR}$ (article no. 15596018; Invitrogen Life Technologies). The tube was stored at room temperature for $1 \mathrm{~h}$ and then incubated at $4^{\circ} \mathrm{C}$ overnight, followed by storage at $-20^{\circ} \mathrm{C}$. The remaining left lung inferior lobe tissue was cut into small pieces, which were placed in cryovials containing glycerol. The cryovials were frozen in liquid nitrogen for $10 \mathrm{~min}$ and then stored at $-70^{\circ} \mathrm{C}$.

Pathology of lung tissue and wetldry ratio (W/D). The connective tissue was removed from the middle lobe of the right lung. The tissue was washed with normal saline at $4^{\circ} \mathrm{C}$ and soaked in paraformaldehyde solution (Invitrogen Biotechnology Co., Ltd., Shanghai, China) for $24 \mathrm{~h}$, followed by conventional dehydration and embedding to create a wax block for microtome cutting. Continuous $4-\mu \mathrm{m}$ slices were prepared and stained with a hematoxylin and eosin staining kit according to the manufacturer's instructions. The pathology status of the lung tissue was observed under an optical microscope and graded in accordance with the criteria for the evaluation of the diffuse alveolar damage (DAD) score $(14,15)$ (Table I). The W/D of the middle lobe of the right lung of the rats was calculated.

Detection of ABCAl mRNA with reverse transcription-fluorescent $q P C R$. Right lung inferior lobe tissue $(100 \mathrm{mg})$, was collected and stored at $-20^{\circ} \mathrm{C}$ prior to extraction of total RNA by the TRIzol $^{\mathrm{TM}}$ method. PCR primers were designed with Primer 5.0 software (Primer, Inc., Ottawa, ON, Canada), and were synthesized by Invitrogen Biotechnology Co., Ltd. (Shanghai, China). The sequences were as follows: ABCA1 upstream primer, 5'-CCCAATCCCAAACACTCC-3' and downstream primer, 5'-GCTACACTGGCACGAAGG-3', product size 133 bp; $\beta$-actin upstream primer,5'-CCCATC TATGAGGGTTACGC-3' and downstream primer, 5'-TTT AATGTCACGCACGATTTC-3', product size $150 \mathrm{bp}$. The reaction conditions for the PCR were as follows: Predenaturation at $95^{\circ} \mathrm{C}$ for $2 \mathrm{~min}$; denaturation at $95^{\circ} \mathrm{C}$ for $10 \mathrm{sec}$, annealing at $60^{\circ} \mathrm{C}$ for $15 \mathrm{sec}$ and elongation at $72^{\circ} \mathrm{C}$ for $20 \mathrm{sec}(40 \mathrm{cycles}$ in total). The fluorescence detection point was set at $72^{\circ} \mathrm{C}$. The cycle threshold (CT) value for each amplicon was measured using a LightCycler 480 fluorescent quantitative PCR instrument (Roche Diagnostics). The ${ }^{\Delta \Delta} \mathrm{CT}$ method was used for relative quantification of the target gene, with the following formula: ${ }^{\triangle} \mathrm{CT}=2-[(\mathrm{CT} 1-\mathrm{CT} 2)-(\mathrm{CT} 3-\mathrm{CT} 4)]$. CT1 and CT2 were the average CT values of the target and housekeeping gene in the control group, respectively. CT3 and CT4 were the average CT values of the corresponding genes in the experimental group respectively.

Analysis of ABCA1 protein expression by western blotting. Right lung inferior lobe tissue $(400 \mathrm{mg})$ stored at $-70^{\circ} \mathrm{C}$ was 
Table I. Evaluation criteria of diffuse alveolar damage.

Diffuse alveolar damage score

Pathological damage

0

1

2

3

Widened alveolar septum

Hemorrhage in alveolar space

Effusion of fibrin in alveolar space

Effusion of neutrophils in alveolar space and alveolar septum

$\begin{array}{ll}\text { Not widened } & \text { Slightly widened } \\ \text { No erythrocytes } & \text { Few erythrocytes }\end{array}$

No erythrocytes

No effusion

No effusion
Slight effusion

Effusion of neutrophils
Obviously widened

Many erythrocytes

Obvious effusion

Scattered effusion
Abnormal alveolar structure

Alveolar space filled with erythrocytes Alveolar space filled with fibrin Obvious effusion or focal distribution used for the extraction of total proteins from the lung tissue subsequent to lysis. The concentration of the extracted proteins was measured using a BCA protein quantification kit. A total of $50 \mu \mathrm{g}$ protein solution was dissolved in $2 \mathrm{X}$ SDS sample loading buffer. The samples were then boiled at $100^{\circ} \mathrm{C}$ for $5 \mathrm{~min}$, followed by separation by $10 \%$ SDS-PAGE. Following electrophoresis, the proteins were transferred to a polyvinylidene difluoride (PVDF) membrane. Blocking solution was made with $10 \mathrm{~g}$ skimmed milk powder added to $200 \mathrm{ml}$ phosphate-buffered saline. The mixture was filtered to prepare 5\% sealing solution. The PVDF membrane was incubated in sealing solution and agitated in a shaker for $2 \mathrm{~h}$, followed by further incubation at $4^{\circ} \mathrm{C}$ overnight. Monoclonal ABCA1 and GAPDH antibodies were added and incubated on the membranes at $37^{\circ} \mathrm{C}$ for $2 \mathrm{~h}$ before washing with Tris-buffered saline with Tween ${ }^{\circledR} 20$, three times. Horseradish peroxidase-labeled rabbit anti-mouse IgG was added to the membranes for $1 \mathrm{~h}$. Following the western blotting, the membranes were developed and scanned and the optical density of the bands was measured using a gel image analysis system. The ratio of ABCA1 to GAPDH optical density was calculated. The band intensity of each group was compared with that of GADPH, and the ratio represented ABCA1 protein expression.

Statistical analysis. The data were processed with Statistical Analysis System (SAS) version 8 software (SAS Institute, Inc., Cary, NC, USA). Measurement data are expressed as the mean \pm standard deviation. One-way analysis of variance was used for comparisons between groups. $\mathrm{P}<0.05$ was considered to indicate a statistically significant difference.

\section{Results}

Pathological changes and DAD score of lung tissue, and W/D of the right lung middle lobe. As shown in Fig. 1, the lung tissue structure of rats in the $\mathrm{N}$ group was normal. The lungs of rats in the $\mathrm{C}$ group had a normal structure and no notable widening of the alveolar septum. The alveolar septum of rats in the L group was widened significantly, and alveolar trapping and effusion in the alveolar space were observed. Similarly, the alveolar septum of rats in the $\mathrm{TP}_{1}$ group was widened, and alveolar trapping and effusion in the alveolar
Table II. Comparison of pathological score and W/D of rats in all groups.

\begin{tabular}{llc}
\hline Group & DAD score & W/D \\
\hline $\mathrm{N}$ & $2.68 \pm 0.36$ & $4.38 \pm 0.12$ \\
$\mathrm{C}$ & $2.55 \pm 0.45$ & $4.29 \pm 0.13$ \\
$\mathrm{~L}$ & $9.68 \pm 1.32^{\mathrm{a}}$ & $6.43 \pm 0.71^{\mathrm{a}}$ \\
$\mathrm{TP}_{1}$ & $9.46 \pm 1.35^{\mathrm{a}}$ & $6.92 \pm 0.68^{\mathrm{a}}$ \\
$\mathrm{TP}_{2}$ & $5.53 \pm 0.86^{\mathrm{a}, \mathrm{b}}$ & $5.18 \pm 0.52^{\mathrm{b}}$ \\
$\mathrm{TP}_{3}$ & $5.58 \pm 0.83^{\mathrm{a}, \mathrm{b}}$ & $4.99 \pm 0.73^{\mathrm{b}}$ \\
\hline
\end{tabular}

${ }^{\mathrm{a}} \mathrm{P}<0.05$ compared with the $\mathrm{N}$ and $\mathrm{C}$ groups; ${ }^{\mathrm{b}} \mathrm{P}<0.05$ compared with the L group. $\mathrm{n}=5$ for all groups. DAD, diffuse alveolar damage; W/D, wet/dry ratio; N, normal group; $\mathrm{C}$, control group; L, LPS-treated group; $\mathrm{TP}_{1-3}$, triptolide-treated group at 25,50 or $100 \mu \mathrm{g} / \mathrm{kg}$, respectively.

space were observed. As compared with the $\mathrm{N}$ and $\mathrm{C}$ groups, the differences in the DAD score of pathological changes and the W/D of the middle lobe of the right lung of the $\mathrm{TP}_{1}$ group were statistically significant $(\mathrm{P}<0.05)$. As compared with the L group, the differences were not statistically significant ( $P>0.05)$. Observations by optical microscopy indicated that the alveolar structure of the $\mathrm{TP}_{2}$ group was normal, with the presence of interstitial edema. Angiotelectasis, congestion and inflammatory cell infiltration were observed. In the $\mathrm{TP}_{2}$ group, the DAD score, representing pathological change, was higher than that in the $\mathrm{N}$ and $\mathrm{C}$ groups, but lower than that in the $\mathrm{L}$ group. The difference in the DAD score between the $\mathrm{TP}_{2}$ and the $\mathrm{L}$ group was statistically significant $(\mathrm{P}<0.05)$ (Table II). In the $\mathrm{TP}_{3}$ group, the alveolar septum was slightly widened, and partial alveolar trapping, interstitial edema, partial angiotelectasis, congestion and inflammatory cell infiltration were observed. As compared with the L group, the differences in the DAD score and W/D of the middle lobe of the right lung in the $\mathrm{TP}_{3}$ group were statistically significant $(\mathrm{P}<0.05)$. However, as compared with the $\mathrm{TP}_{2}$ group, the differences were not statistically significant $(\mathrm{P}>0.05)$ (Table II).

Arterial blood gas analysis. The differences in $\mathrm{PaO}_{2}$ at 3,6 and $12 \mathrm{~h}$ between the $\mathrm{L}$ and $\mathrm{TP}_{1}$ groups and the $\mathrm{N}$ and $\mathrm{C}$ groups were statistically significant $(\mathrm{P}<0.05)$. In addition, the differences in $\mathrm{PaO}_{2}$ at 3,6 and $12 \mathrm{~h}$ between the $\mathrm{TP}_{2}$ and $\mathrm{TP}_{3}$ groups 

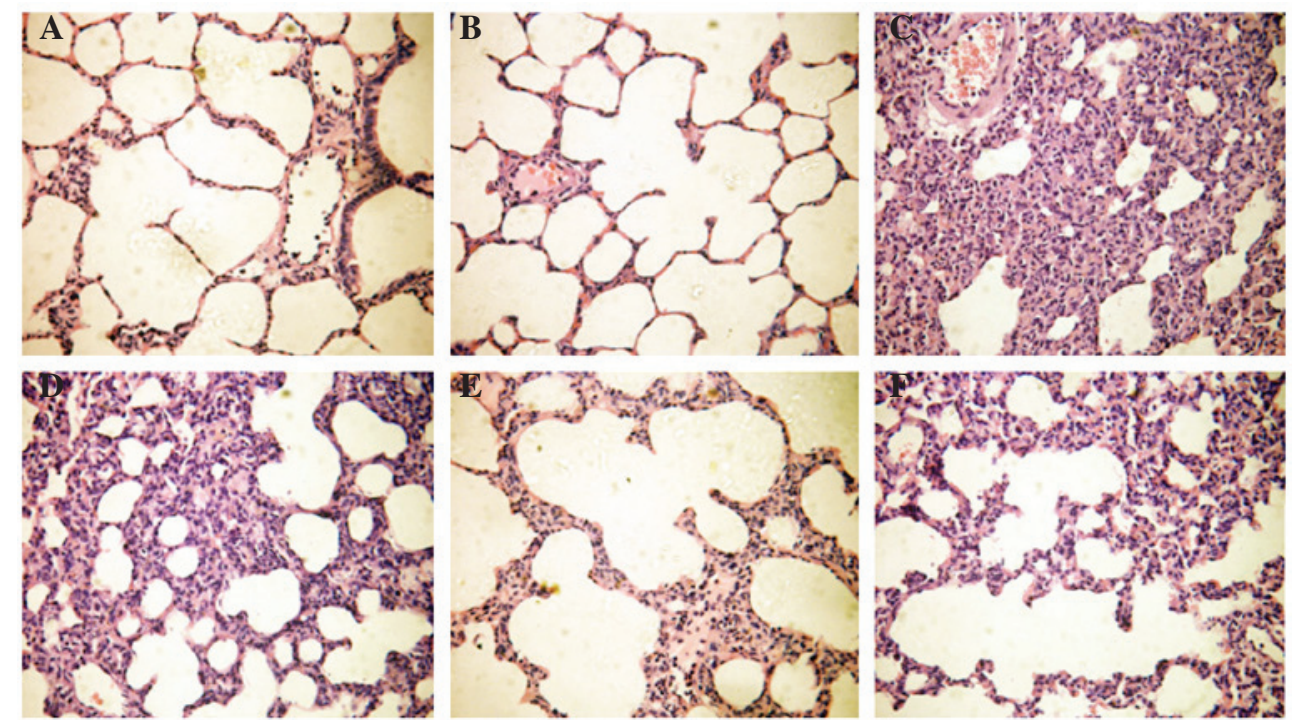

Figure 1. Figure 1. Pathological changes in the lungs of rats in all groups (hematoxylin and eosin staining; magnification, $\mathrm{x} 400$ ). (A) The lung tissue structure of rats in the $\mathrm{N}$ group was normal. (B) The alveolar septum of rats in the $\mathrm{C}$ group was not notably widened and the structure was basically normal. (C) A notably widened alveolar septum, alveolar trapping and effusion in the alveolar space were observed in the L group. (D) A widened alveolar septum, alveolar trapping and effusion in the alveolar space were observed in the $\mathrm{TP}_{1}$ group. (E) Under the optical microscope, the alveolar structure in the $\mathrm{TP}_{2}$ group was basically normal, although interstitial edema, partial angiotelectasis, congestion and inflammatory cell infiltration were observed. (F) A slightly widened alveolar septum, edema, partial alveolar trapping, angiotelectasis, congestion and inflammatory cell infiltration were observed in the $\mathrm{TP}_{3}$ group. $\mathrm{N}$, normal group; $\mathrm{C}$, control group; L, LPS-treated group; $\mathrm{TP}_{1-3}$, triptolide treated group at 25,50 or $100 \mu \mathrm{g} / \mathrm{kg}$, respectively.

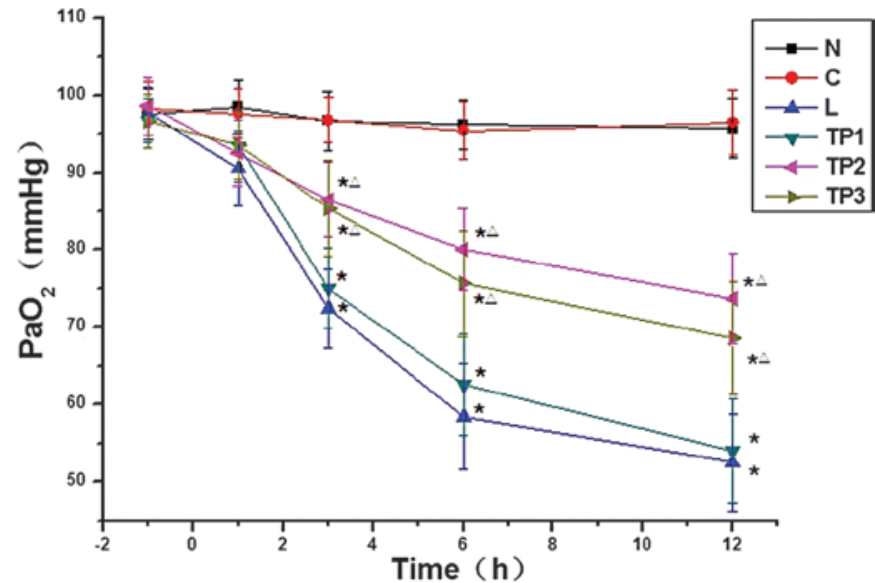

Figure 2. Arterial blood gas analysis of rats in all groups. "P $<0.05$ compared with the $\mathrm{N}$ and $\mathrm{C}$ groups at the same time-point. ${ }^{\wedge} \mathrm{P}<0.05$ compared with the $\mathrm{L}$ group at the same time-point. N, normal group; $\mathrm{C}$, control group; L, LPS-treated group; TP1-3, triptolide-treated group at 25,50 or $100 \mu \mathrm{g} / \mathrm{kg}$, respectively; $\mathrm{PaO}_{2}$, arterial oxygen tension.

and the $\mathrm{N}$ and $\mathrm{C}$ groups were statistically significant $(\mathrm{P}<0.05)$. The $\mathrm{PaO}_{2}$ in the $\mathrm{TP}_{2}$ and $\mathrm{TP}_{3}$ groups was relatively high as compared with that in the $\mathrm{L}$ and $\mathrm{TP}_{1}$ groups, and the differences were statistically significant $(\mathrm{P}<0.05)$ (Fig. 2).

Changes in TNF- $\alpha$ expression in serum and BALF. The expression levels of TNF- $\alpha$ in the serum and BALF were increased at $12 \mathrm{~h}$ in the $\mathrm{L}$ and $\mathrm{TP}_{1}$ groups. As compared with the $\mathrm{N}$ and $\mathrm{C}$ groups, the differences were statistically significant $(\mathrm{P}<0.05)$. The TNF- $\alpha$ expression in the serum and BALF at $12 \mathrm{~h}$ in the $\mathrm{TP}_{2}$ and $\mathrm{TP}_{3}$ groups was decreased as compared with that in the $\mathrm{L}$ and $\mathrm{TP}_{1}$ groups. These differences were statistically significant $(\mathrm{P}<0.05)$. As compared with the $\mathrm{N}$ and

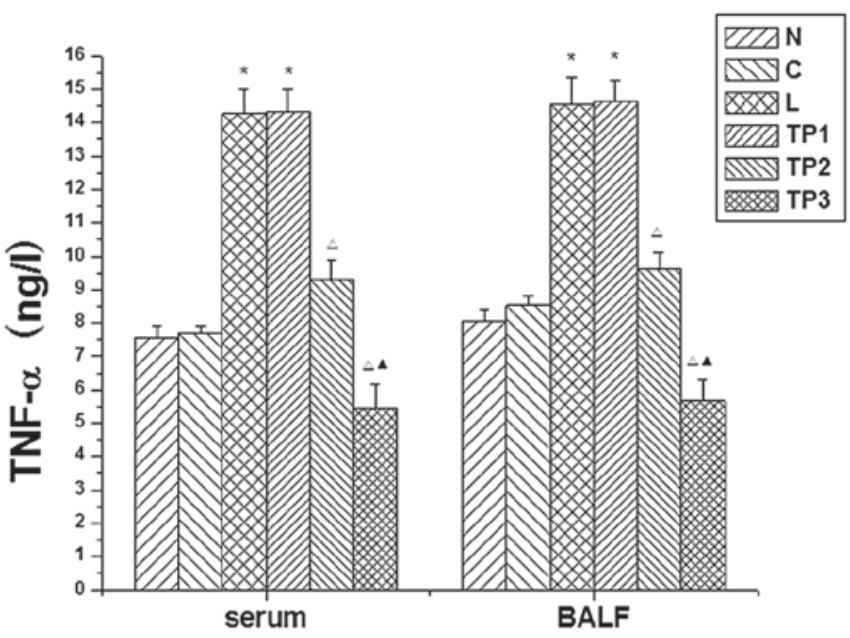

Figure 3. Changes in TNF- $\alpha$ expression in the serum and BALF of rats in all groups. ${ }^{*} \mathrm{P}<0.05$ compared with the $\mathrm{N}$ and $\mathrm{C}$ groups. ${ }^{\Delta \mathrm{P}}<0.05$, compared with the $\mathrm{N}$ and $\mathrm{C}$ group. $\mathrm{N}$, normal group; $\mathrm{C}$, control group; L, LPS-treated group; TP1-3, triptolide-treated group at 25,50 or $100 \mu \mathrm{g} / \mathrm{kg}$, respectively; BALF, bronchoalveolar lavage fluid; TNF- $\alpha$, tumor necrosis factor $\alpha$.

$\mathrm{C}$ groups, the expression of TNF- $\alpha$ in the serum and BALF in the $\mathrm{TP}_{3}$ group was significantly decreased $(\mathrm{P}<0.05)$ (Fig. 3).

Analysis of ABCA1 expression in lung tissue. The mRNA and protein expression levels of ABCA1 in the L group were significantly decreased as compared with those in the $\mathrm{N}$ and $\mathrm{C}$ groups $(\mathrm{P}<0.05)$. With the increasing doses of triptolide, the mRNA and protein expression of ABCA1 in the $\mathrm{TP}_{2}$ and $\mathrm{TP}_{3}$ groups showed an increasing trend. As compared with the $\mathrm{L}$ group, the corresponding expression of ABCA1 in the $\mathrm{TP}_{2}$ group was significantly increased $(\mathrm{P}<0.05)$. As compared with the $\mathrm{TP}_{2}$ group, the mRNA and protein expres- 


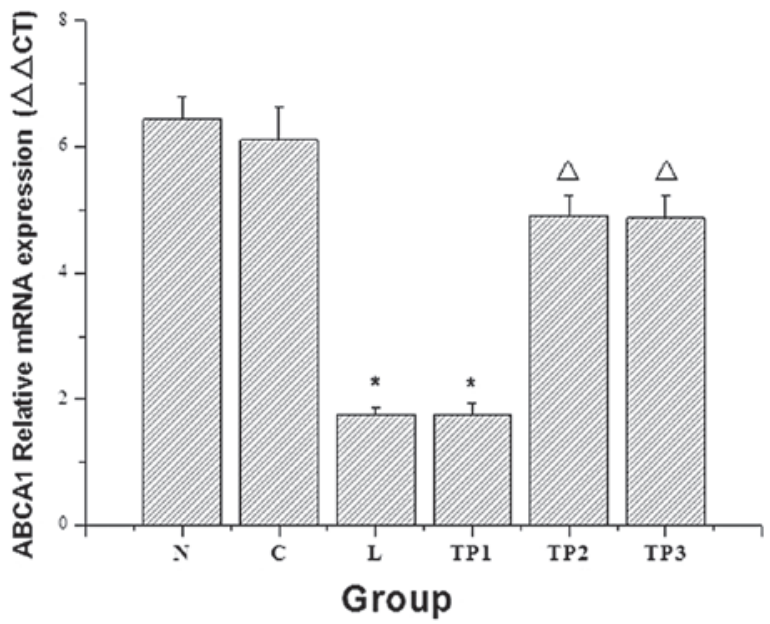

Figure 4. Changes in ABCA1 mRNA expression in the lung tissue of rats in all groups. ${ }^{*} \mathrm{P}<0.05$ compared with the $\mathrm{N}$ and $\mathrm{C}$ groups. ${ }^{\Delta} \mathrm{P}<0.05$ compared with the L group. N, normal group; C, control group; L, LPS-treated group; TP1-3, triptolide treated group at 25,50 or $100 \mu \mathrm{g} / \mathrm{kg}$, respectively; ABCA1, ATP-binding cassette transporter A1.
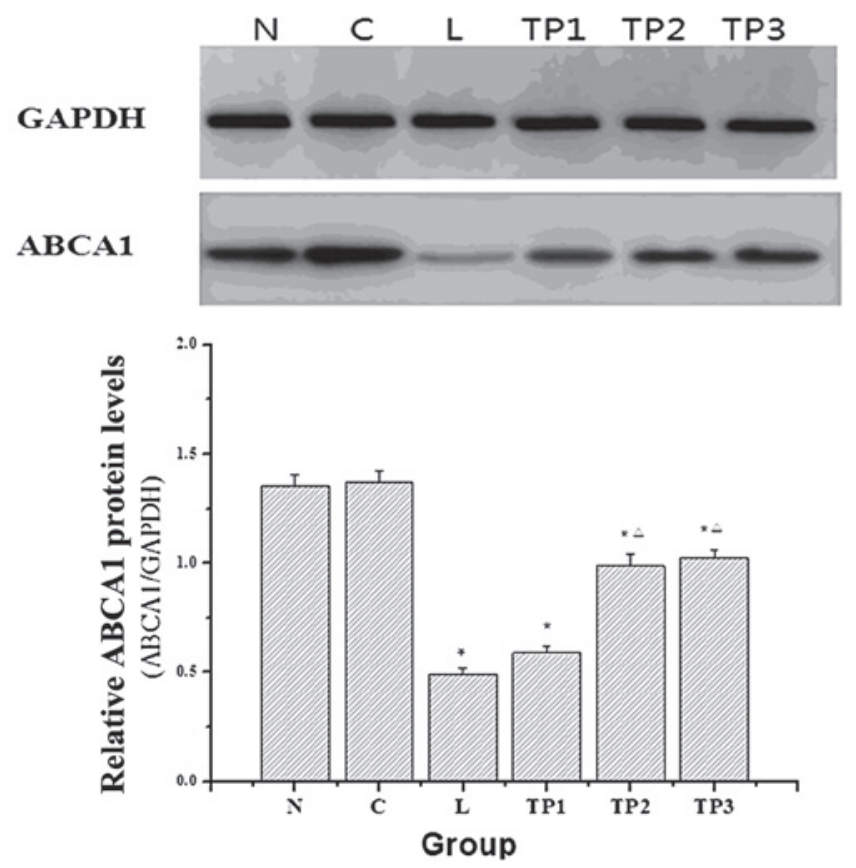

Figure 5. ABCA1 protein expression in lung tissue. ${ }^{*} \mathrm{P}<0.05$ compared with the $\mathrm{N}$ and $\mathrm{C}$ groups. ${ }^{\Delta} \mathrm{P}<0.05$ compared with the $\mathrm{L}$ group. $\mathrm{N}$, normal group; C, control group; L, LPS-treated group; TP1-3, triptolide-treated group at 25, 50 or $100 \mu \mathrm{g} / \mathrm{kg}$ respectively; ABCA1, ATP-binding cassette transporter A1.

sion levels of $\mathrm{ABCA} 1$ in the $\mathrm{TP}_{3}$ group were not significantly different ( $\mathrm{P}>0.05)$ (Figs. 4 and 5).

\section{Discussion}

The inflammatory response and the changes in the expression of active substances on the lung surface play an important role in the pathogenesis of LPS-mediated ALI. The regulation of signaling factors at the molecular level, in addition to the termination of the cytokine chain reaction (16-20), may be areas in which targeted therapies could be designed. ABCA1 is a transmembrane protein that is most highly expressed in the lung. In the lung, the protein expression of ABCA1 is closely associated with the inflammatory response $(6,7,10,11)$, and ABCA1-mediated cholesterol transport activity is correlated with the anti-inflammatory activity of ABCA1. Adjustments to the lipid composition in the lipid raft region may be the potential mechanism underlying the ABCA1-mediated inflammatory regulation. LPS stimulates alveolar macrophages in ABCA1-knockout rats, which leads to an increase in the expression of pro-inflammatory cytokine, as well as the activation of the nuclear factor $\kappa$-light-chain-enhancer of activated B cells-mitogen-activated protein kinase pathway $(21,22)$.

In this study, rats were injected with endotoxin (LPS) through the caudal vein. Twelve hours after the LPS challenge, the $\mathrm{PaO}_{2}$ of each group was analyzed. The $\mathrm{PaO}_{2}$ of each of the LPS-treated groups was observed to be significantly decreased 3, 6 and $12 \mathrm{~h}$ after injection compared with that of the $\mathrm{N}$ and $\mathrm{C}$ groups $(\mathrm{P}<0.05)$. Additionally, the BALF and TNF- $\alpha$ serum expression levels, the pathological changes in the rat lung tissue and the W/D were concordant with the criteria of an animal model of ALI as compared with the C group. Compared with the $\mathrm{C}$ and $\mathrm{N}$ groups, ABCA1 gene and protein expression in the $\mathrm{L}$ group was respectively reduced, and these differences were statistically significant $(\mathrm{P}<0.05)$. These data preliminarily suggest that ABCA1 is involved in the formation and development of ALI/ARDS.

The results of this study showed that ABCA1 mRNA and protein expression levels in the $\mathrm{TP}_{2}$ and $\mathrm{TP}_{3}$ groups increased with the increasing dose of triptolide. Compared with the L group, the ABCA1 mRNA and protein expression levels were significantly different $(\mathrm{P}<0.05)$. When $50 \mu \mathrm{g} / \mathrm{kg}$ was exceeded, there was no notable change. The analysis of $\mathrm{PaO}_{2}$ at 3, 6 and $12 \mathrm{~h}$ after injection indicated that $\mathrm{PaO}_{2}$ was significantly higher in the $\mathrm{TP}_{2}$ and $\mathrm{TP}_{3}$ groups as compared with that in the $\mathrm{L}$ group $(\mathrm{P}<0.05)$. The $\mathrm{W} / \mathrm{D}$ in the $\mathrm{TP}_{2}$ and $\mathrm{TP}_{3}$ groups was lower than that in observed in the $\mathrm{L}$ group $(\mathrm{P}<0.05)$. The degree of pathological change in the lung was low in the $\mathrm{TP}_{2}$ and $\mathrm{TP}_{3}$ groups and, compared with the $\mathrm{L}$ group, the differences in pathological score were statistically significant $(\mathrm{P}<0.05)$. TNF- $\alpha$ expression in the serum and BALF in the $\mathrm{TP}_{2}$ and $\mathrm{TP}_{3}$ groups was significantly decreased $12 \mathrm{~h}$ after injection, as compared with the $\mathrm{L}$ group $(\mathrm{P}<0.05)$.

The results of the present study suggest that triptolide is capable of promoting the expression of ABCA1, reducing the secretion of inflammatory factors and relieving the lung pathological injury associated with ALI. Therefore, it is speculated that the regulation of ABCA1 gene and protein expression by triptolide may be a potential strategy for lung protection. Within a range of $25-100 \mu \mathrm{g} / \mathrm{kg}$ triptolide, the regulation of ABCA1 gene and protein expression was dose-dependent, however, $100 \mu \mathrm{g} / \mathrm{kg}$ was considered to be the threshold dose for dose-dependent effects.

\section{References}

1. Leaver SK and Evans TW: Acute respiratory distress syndrome. BMJ 335: 389-394, 2007.

2. Goodman RB, Strieter RM, Martin DP, et al: Inflammatory cytokines in patients with persistence of the acute patients with persistence of the acute respiratory distress syndrome. Am J Respir Crit Care Med 154: 602-611, 1996. 
3. Beck-Schimmer B, Schwendener R, Pasch T, et a1: Alveolar macrophages regulate neutrophil recruitment in endotoxin-induced lung injury. Respir Res 6: 61, 2005.

4. Armstrong L and Millar AB: Relative production of tumour necrosis factor alpha and interleukin 10 in adult respiratory distress syndrome. Thorax 52: 442-446, 1997.

5. Bhatia M and Moochhala S: Role of inflammatory mediators in the pathophysiology of acute respiratory distress syndrome. J Pathol 202: 145-146, 2004.

6. Zhu X, Lee JY, Timmins JM, et al: Increased cellular free cholesterol in macrophage-specific ABCA1 knock-out mice enhances pro-inflammatory response of macrophages. J Biol Chem 283: 22930-22941, 2008.

7. Yin K, Liao DF and Tang CK: ATP-binding membrane casette transporter A1 (ABCA1): A possible link between inflammation and reverse cholesterol transport. Mol Med 16: 438-449, 2010.

8. Tang C, Liu Y, Kessler PS, et al: The macrophage cholesterol exporter ABCA1 functions as an anti-inflammatory receptor. J Biol Chem 284: 32336-32343, 2009.

9. Ying J, Ma YM and Pei WY: Research progress and application of pulmonary surfacetant. Chin Pham J 19: 1449-1453, 2005 (In Chinese).

10. Bates SR, Tao JQ, Collins HL, et al: Pulmonary abnormalities due to ABCA1 deficiency in mice. Am J Physiol Lung Cell Mol Physiol 289: L980-L989, 2005.

11. Zhao G, Vaszar LT, Qiu D, et al: Anti-inflammatory effects of triptolide in human bronchial epithelial cells. Am J Physiol Lung Cell Mol Physiol 279: L958-L966, 2000.

12. Tengchaisri $\mathrm{T}$, Chawengkirttikul $\mathrm{R}$, Rachaphaew $\mathrm{N}$, et al: Antitumor activity of triptolide against cholangiocarcinoma growth in vitro and in hamsters. Cancer Lett 133: 169-175, 1998.
13. Feng Y, Yang Q, Xu J,et al: Effects of HMGB1 on PMN apoptosis during LPS-induced acute lung injury. Exp Mol Pathol 85: 214-222, 2008

14. Yokoyama T, Tomiguchi S, Nishi J, et al: Hyperoxia-induced acute lung injury using a pig model: correlation between MR imaging and histologic results. Radiat Med 19: 131-143, 2001.

15. Gao JL, Chen J, Zhan Y and Wang LN: Effects of triptolide on lipopolysaccharide-induced acute lung injury in rats. Chin JAnesthesiol 31: 1245-1248, 2011.

16. Metz C and Sibbald WJ: Anti-inflammatory therapy for acute lung injury. A review of animal and clinical studies. Chest 100: 1110-1119, 1991.

17. St. John RC and Dorinsky PM: Immunologic therapy for ARDS, septic shock, and multiple organ failure. Chest 103: 932-943, 1993.

18. Downey GP and O'Brodovich HM: Mechanisms of acute lung injury and repair. In: Pediatric Respiratory Medicine. Taussig L (ed). Mosby, St. Louis, MO, pp76-91, 1997.

19. Downey GP, Dong Q, Kruger J, et al: Regulation of neutrophil activation in acute lung injury. Chest (1 Suppl) 116: 46S-54S, 1999.

20. Heering P, Morgera S, Schmitz FJ, et al: Cytokine removal and cardiovascular hemodynamics in septic patients with continuous venovenous hemofiltration. Intensive Care Med 23: 288-296, 1997.

21. Zhu X, Owen JS, Wilson MD, et al: Macrophage ABCA1 reduces MyD88-dependent Toll-like receptor trafficking to lipid rafts by reduction of lipid raft cholesterol. J Lipid Res 51: 3196-3206, 2010.

22. Zhu X, Lee JY, Timmins JM, et al: Increased cellular free cholesterol in macrophage-specific Abcal knock-out mice enhances pro-inflammatory response of macrophages. J Biol Chem 283: 22930-22941, 2008. 